\title{
JNPH
}

Volume 6 No. 2 (Oktober 2018)

(C) The Author(s) 2018

\section{KEBERADAAN BAKTERI ESHERICHIA COLI PADA SUMBER AIR MINUM DI DESA MAMALA MALUKU TENGAH}

\author{
THE PRESENCE OF ESHERICHIA COLI BACTERIA IN DRINKING WATER \\ SOURCES IN MAMALA VILLAGE CENTRAL MALUKU
}

\author{
PRASETYAWATI, RIZAL MALAWAT \\ POLITEKNIK KESEHATAN KEMENTERIAN KESEHATAN MALUKU \\ E-mail : watick.one@gmail.com
}

\begin{abstract}
ABSTRAK
Penggunaan air yang tidak memenuhi persyaratandapat menimbulkan terjadinya gangguan kesehatan. Gangguan kesehatan tersebut dapat berupa penyakit menular maupun penyakit tidak menular. Penyakit menular umumnya disebabkan oleh makhluk hidup, penyakit menular yang disebarkan oleh air secara langsung di masyarakat disebut penyakit bawaan air atau water borne disease. Ini terjadi karena air merupakan media yang baik untuk berkembangbiak agent penyakit. Selain penyakit menular, penggunaan air dapat juga memicu penyakit tidak menular karena telah terkontaminasi zat-zat berbahaya atau beracun. Jenis penelitian ini adalah penelitian Deskriptif. Populasi dalam penelitian ini adalah seluruh sumber mata air yang ada di Desa Mamala dan sampel diambil sebanyak 6 sampel dari 3 sumber mata air. Hasil pemeriksaan dari semua sampel pada sumber air minum di Desa Mamala, Maluku Tengah positif mengandung bakteri Esherichia coli. Saran : diharapkan kepada masyarakat setempat agar mengkonsumsi air minum yang sudah dimasak terlebih dahulu serta lebih meningkatkan wawasan dan pengetahuan tentang pentingnya kesehatan.
\end{abstract}

\section{Kata Kunci: Bakteri, Esherichia Coli, Sumber Air Minum}

\begin{abstract}
The use of water that does not meet the requirements can cause health problems. These health problems can be in the form of infectious diseases and non-communicable diseases.Infectious diseases are generally caused by living things, infectious diseases spread by water directly in the community are called water borne diseases. This happens because water is a good medium for breeding disease agents. In addition to infectious diseases, the use of water can also trigger non-communicable diseases because they have been contaminated with harmful or toxic substances. This type of research is descriptive research. The population in this study is all sources of springs in Mamala Village and the samples are taken as many as 6 samples from 3 springs. The results of the examination of all samples at the source of drinking water in the Mamala village of Central Maluku were positive for Esherichia coli bacteria. Suggestion: It is hoped that the local community will consume drinking water that has been cooked in advance and further enhance insight and knowledge about the importance of health.
\end{abstract}

Keywords: Bacteria, Esherichia Coli, Drinking Water Source 


\section{PENDAHULUAN}

Air adalah cairan yang tidak berwarna, tidak berasa, dan tidak berbau. Air tidak dapat dipisahkan dari kehidupan manusia. Bahkan dapat dipastikan tanpa pengembangan sumberdaya air yang konsisten peradaban manusia tidak akan mencapai tingkat yang dinikmati saat ini. Pengembangan dan pengolahan sumberdaya air merupakan dasar peradaban manusia.

Air bagi tubuh kita adalah sebagai pengganti ion tubuh, setelah seharian kita menjalani berbagai aktivitas yang melelahkan yang menyebabkan berkurangnya energi dalam tubuh kita. Selain itu, air sangat dibutuhkan sebagai pelepas dahaga yang baik bagi kesehatan tubuh kita. Tubuh kita sekitar $70 \%$ nya terdiri dari cairan. Cairan dalam tubuh memiliki fungi masing-masing, diantaranya adalah sebagai proses pencernaan, penyerapan sari makanan, dan masih banyak lagi, untuk itu sangat dianjurkan untuk mengkonsumsi air (Suripin, 2008).

Air yang dikonsumsi manusia harus berasal dari sumber yang bersih dan aman diantaranya bebas kontaminasi kuman, bebasdarisubstansikimia yang berbahaya dan beracun. Air yang memenuhi persyaratan fisik adalah tidak keruh, tidak berbau, tidak berasa, tidak berwarna dan terasa sejuk atau tidak hangat.Penggunaan air yang tidak memenuhi persyaratan dapat menimbulkan terjadinya gangguan kesehatan.Gangguan kesehatan tersebut dapat berupa penyakit menular maupun penyakit tidak menular. Penyakit menular umumnya disebabkan oleh makhluk hidup, penyakit menular yang disebarkan oleh air secara langsung di masyarakat disebut penyakit bawaan air atau waterborne disease. Ini terjadi karena air merupakan media yang baik untuk berkembangbiak agent penyakit. Selain penyakit menular, penggunaan air dapat juga memicu penyakit tidak menular karena telah terkontaminasi zat-zat berbahaya atau beracun.

Peraturan Menteri Kesehatan No. 416 Tahun 1990 Tentang : Syarat-syarat dan
Pengawasan Kualitas Air. Menteri Kesehatan Republik Indonesia, menimbang bahwa dalam rangka meningkatkan derajat kesehatan masyarakat, perlu dilaksanankan pengawasan kualitas air secara intensif dan terus menerus, bahwa kualitas air yang digunakan masyarakat harus memenuhi syarat kesehatan agar terhindar dari gangguan kesehatan, bahwa syarat-syarat kualitas air yang berhubungan dengan kesehatan yang telah ada perlu disesuaikan dengan perkembangan teknologi dan upaya kesehatan serta kebutuhan masyarakat dewasa ini.

Presentasi banyaknya rumah tangga dan sumber air minum yang digunakan di berbagai daerah di Indonesia sangat bervariasi tergantung dari kondisi geografisnya. Secara nasional yakni sebagai berikut: yang menggunakan air (PAM) 16,08 \%, air tanah dengan memakai pompa $11,61 \%$, air sumur $49,92 \%$, mata air 13,92, air sungai 4,91\%, air hujan 2,62\% danlainnya $0,80 \%$.

Air yang mengadung Esherichia coli dianggap telah terkontaminasi (berhubungan) dengan kotoran manusia. Secara umum dalam pemeriksaan bakteriologis air, tidaklah langsung air itu diperiksa pada kandungan bakteri pathogen, namun yang diperiksa adalah indikator Esherichia coli yang dipandang bisa mewakili kehidupan bakteri pathogen lainnya. Untuk standar dan parameter kualitas bakteriologis air, hingga saat ini perangkat yang memberikan batasan kandungan yang diperbolehkan adalah Permenkes No. 416/Menkes/PER/IX/1990. Dalam Permenkes ini parameter bakteriologis disebutkan untuk air minum kandungan Esherichia coli dalam setiap $2 \mathrm{ml}$ ada 20 koloni sampel (air perpipaan) dan mengacu pada

Kepmenkes No.907/Menkes/SK/VII/2002, menyebutkan untuk air minum kandungan maksimum Coliform adalah 0 koloni per $100 \mathrm{ml}$ sampel.

\section{METODE PENELITIAN}

Jenis penelitian ini adalah penelitian Deskriptif yang bertujuan untuk mengetahui 
gambaran Escherichia coli pada sumber air minum.

Hasil identifikasi Esherichia coli pada sumber air minum disajikan dalam bentuktabel dan dianalisis secara univariat. Lokasi pengambilan sampel dilakukan di tiga sumber air minum dengan 2 titik pada tiaptiap sumber. di Desa Mamala, Maluku Tengah. Sedangkan lokasi penelitian dilaksanakan di Laboratorium Kesehatan Daerah Provinsi Malukudengan alokasi waktu penelitian selama 1 bulan.

\section{HASIL PENELITIAN}

Tabel 1. Distribusi Keberadaan Bakteri Esherichia coli pada sumber air minum

\begin{tabular}{|c|c|c|c|c|}
\hline \multirow{2}{*}{ No } & \multirow{2}{*}{ Sampel } & \multicolumn{2}{|c|}{ Hasil Uji } & \multirow{2}{*}{$\begin{array}{c}\text { Jumlah } \\
\text { Esherichia } \\
\text { coli }\end{array}$} \\
\hline & & Positif & Negatif & \\
\hline \multirow[t]{3}{*}{1} & Sumber 1 & & & \\
\hline & $\mathrm{A}_{1}$ & $\mathrm{P}$ & - & $\begin{array}{c}1898 / 100 \\
\mathrm{ml}\end{array}$ \\
\hline & $\mathrm{A}_{2}$ & $\mathrm{P}$ & - & $95 / 100 \mathrm{ml}$ \\
\hline \multirow[t]{3}{*}{2} & Sumber 2 & & & \\
\hline & $\mathrm{B}_{1}$ & $\mathrm{P}$ & - & $\begin{array}{c}1898 / 100 \\
\mathrm{ml}\end{array}$ \\
\hline & $\mathrm{B}_{2}$ & $\mathrm{P}$ & - & $271 / 100 \mathrm{ml}$ \\
\hline \multirow[t]{3}{*}{3} & Sumber 3 & & & \\
\hline & $\mathrm{C}_{1}$ & $\mathrm{P}$ & - & $\begin{array}{c}1898 / 100 \\
\mathrm{ml}\end{array}$ \\
\hline & $\mathrm{C}_{2}$ & $\mathrm{P}$ & - & $\begin{array}{c}1898 / 100 \\
\mathrm{ml}\end{array}$ \\
\hline & imlah & 6 & 0 & 6 \\
\hline
\end{tabular}

Berdasarkan tabel 1, dapat dilihat bahwa semua sumber air minum di Desa Mamala, Maluku Tengah positif mengandung bakteri Esherichia coli.

\section{PEMBAHASAN}

Pada penelitian ini sampel yang diperiksa sebanyak 6 sampel, yang bersumber dari masing-masing lokasi penelitian diambil sebanyak $600 \mathrm{ml}$ dari berbagai sumber air minum di Desa Mamala. Keesokan harinya sampel dibawa dan diperiksa secara langsung di Instalasi Mikrobiologi Balai Laboratorium
Kesehatan Provinsi Maluku dengan Metode MPN (Most Probable Number) yang terdiri dari uji presumtif (penduga) dan uji konfirmasi (pendugaan), dengan menggunakan media cair di dalam tabung reaksi dan dilakukan berdasarkan jumlah tabung positif. Pengamatan tabung positif dapat dilihat dengan timbulnya gas di dalam tabung Durham.

Pemeriksaan diawali dengan memindahkan sebanyak $1 \mathrm{ml}$ larutan pengenceran $10^{-1}$ dengan pipet steril ke dalam $9 \mathrm{ml}$ larutan LB untuk mendapatkan pengenceran $10^{-2}$ dan kemudian dibuat juga untuk mendapatkan pengenceran $10^{-3}$. Kemudian pindahkan masing-masing $1 \mathrm{ml}$ dari setiap pengenceran ke dalam 3 seri tabung LB yang berisi tabung Durham dan diinkubasi selama $24-48$ jam dengan temperatur $37^{\mathrm{O}} \mathrm{C}$. Setelah mendapatkan biakan positif yang ditandai dengan adanya gas pada tabung Durham, dengan menggunakan jarum inokulasi dari setiap tabung LB ke dalam tabung BGLB yang juga berisi tabung Durham dan di inkubasikan kembali pada temperatur $37^{\mathrm{O}} \mathrm{C}$ selama 48 jam. Hasil positif di tandai dengan terbentuknya gas pada tabung Durham.

Hasil pengamatan pada sumber 1 (A1), Sumber 2 (B1) dan sumber 3 (C1 dan C2) positif mengandung bakteri Esherichia colidengan jumlah yang lebih tinggi disebabkan karena tempat penampungan air tersebut terbuka dan berada di alam bebas sehingga air mengalami pencemaran yang disebabkan oleh bakteri.

Hasil penelitian yang dilakukan oleh Alban Ramadhan (2016) pada air sumur di Terminal Tirtonadi Surakarta terdapat 6 sampel air sumur gali yang ternyata manunjukkan bahwa seluruh sampel air yang diperiksa mengandung bakteri Escherichia coli dengan jumlah yang bervariasi dari 1387,7 sampai dengan $>2,400$ bakteri Escherichia coli per $100 \mathrm{ml}$ air. Variasi jumlah Escherichia coli tersebut yang melebihi nilai maksimum air tanpa pipa yaitu $<50$ bakteri Escherichia coli per $100 \mathrm{ml}$. 
Sehingga semua sampel air sumur gali tersebut tidak memenuhi syarat sebagai sumber air bersih. Berbeda dengan sampel sumur air bor 5 sampel yang diperiksa menunjukan bahwa total Escherichia coli berkisar $<10$ bakteri Escherichia coli per 100 $\mathrm{ml}$ air sehingga sesuai dengan syarat nilai maksimum air pipa dan air tersebut layak digunakan sebagai sumber air bersih.

Sedangkan pada sumber 1 (A2) dan sumber 2 (B2) juga positif mengandung bakteri Esherichia colinamun dengan jumlah yang lebih rendah hal ini disebabkan karenadalam 2 minggu kran selalu dibersihkan dan sebelum pengambilan sampel kran distrerilkan terlebih dahulu sehingga bakteri Esherichia coli yang terdapat pada mulut kran sudah berkurang.

Hasil penelitian yang dilakukan oleh Ima Fitha Patasik dan Daniel Lantang (2009) pada Sumber Air Minum Masyarakat Kampung Yokiwa Distrik Sentani Timur Secara Bakteriologis diperoleh pada 3 (tiga) titik pengambilan sampel tersebut, dapat dilihat bahwa daerah muara Danau Sentani (sampel A) dan daerah aliran Sungai Jaifuri (sampel C) memiliki jumlah Coliform yang sama yaitu $46.000 \mathrm{MPN} / 100 \mathrm{ml}$ sampel air, sedangkan pada sampel B yang berada diantara daerah muara danau sentani dan sungai Jaifuri memiliki jumlah Coliform yang lebih rendah yaitu $15.000 \mathrm{MPN} / 100 \mathrm{ml}$ sampel air. Hasil nilai MPN yang diperoleh dari 3 titik pengambilan sampel pada air keluaran (outlet) Danau Sentani tersebut menunjukkan bahwa air keluaran (outlet) Danau Sentani memiliki kadar jumlah Coliform yang melebihi batas kadar maksimum yang diperbolehkan untuk syarat air minum yaitu $0 / 100 \mathrm{ml}$ sampel air.

Hal ini menunjukkan bahwa Pemerintah Desa Mamala mungkin belum menerapkan hygiene dan sanitasi yang baik karena melalui hasil pemeriksaan, sumber air minum masih belum memenuhi syarat bakteriologis. Hasil pemeriksaan pada seluruh sampel menunjukkan hasil positif mengandung bakteri Esherichia coli dengan jumlah yang sangat tinggi. Keberadaan bakteri Esherichia coliumumnya normal berada di feses manusia dan hewan. Keberadaannya dapat menandakan telah terjadi kontaminasi tinja pada sumber air dan memungkinkan terdapat bakteri patogen lain di dalam air. Temuan ini hampir sama dengan penelitian sebelumnya yang pernah dilakukan di Kelurahan Andalas Kecamatan Padang Timur, Padang pada tahun 2015. Pada penelitian tersebut didapatkan 94\% kualitas air di Daerah tersebut tidak memenuhi syarat bakteriologis (Kusuma, Rasyid \& Endrinaldi, 2015)

Selain itu, keberadaan bakteri Esherichia coli juga dapat menandakan bahwa pada sampel sumber air mungkin terjadi kontaminasi dari tanah, karena bakteri ini juga banyak di tanah dan juga ada kontaminasi dari feses, karena bakteri terdapat di saluran cerna. Kontaminasi yang terjadi dapat berasal dari kurang menjaga kebersihan terutama di tempat penampung air dan pipa-pipa yang yang di salurkan ke warga. Hal ini akan berakibat buruk terhadap masyarakat itu sendiri apabila sumber air minum yang digunakan terkontaminasi dengan bakteri Esherichia colikarena dapat mengakibatkan gangguan kesehatan seperti mual, nyeri perut, muntah, diare, tinja darah, demam tinggi bahkan pada beberapa kasus bisa mengakibatkan kejang dan kekurangan cairan atau dehidrasi (Sakti, 2012).

Total 6 sampel sumber air minum yang berasal dari Desa Mamala Maluku Tengah yang diteliti, didapatkan hasil positif pada seluruh sampel dengan nilai indeks MPN yang tinggi. Hal ini menandakan bahwa sumber air minum yang digunakan tidak memenuhi kriteria bakteriologis untuk air bersih sesuai dengan PERMENKES No. 416 tahun 1990. Hygiene dan sanitasi memiliki peran penting dalam pencemaran bakteri di sumber air minum tersebut.

\section{KESIMPULAN}

Berdasarkan hasil penelitian yang dilakukan di Instalasi Mikrobiologi Balai Laboratorium Kesehatan Provinsi Maluku 
dapat disimpulkan bahwa dari 6 sampel sumber air minum di Desa Mamala positif mengandung bakteri Esherichia coli

\section{SARAN}

Diharapkan kepada masyarakat setempat agar mengkonsumsi air minum yang sudah dimasak terlebih dahulu serta lebih meningkatkan wawasan dan pengetahuan tentang pentingnya kesehatan.

\section{DAFTAR PUSTAKA}

Akademi Analis Kesehatan Nasional Surakarta (2012). Escherichia colidan proteus mirabilis. Surakarta : Akademi Analis Kesehatan Surakarta

Alban Ramadhan, 2016. Perbandingan Bakteri Escherichia coli Pada Sumber Air Minum Gali Dengan Sumber Air Minum Sumur Bor di Terminal Tirtonadi Surakarta (Skripsi). Universitas Muhammadiyah Surakarta : 2016

Ima Fitha dkk, 2009. Kualitas Sumber Air Minum Masyarakat Kampung Yokiwa Distrik Sentani Timur Secara Bakteriologis. Jurnal Biologi Papua. Jurusan Biologi FMIPA Universitas Cendrawasih, Jayapura-Papua.

Notoatmodjo, Soekidjo. (2010). Metodologi Penelitian Kesehatan. Jakarta: P.T Rineka Cipta.

Pemerintah Desa Mamala (2016) Gambaran Umum Desa Mamala Kecamatan Leihitu Kabupaten Maluku Tengah. Ambon.

Peraturan Menteri Kesehatan RI No.492/MENKES/PER/IV/2010 tentang Persyaratan Kualitas Air Minum.

Prasetyo, A. D. (2009). Uji MPN Coliformpada pengolahan Air MP SDH. AKAFARMA, 1-20.

Pustu Desa Mamala (2016).Buku Rekapan Daftar Kunjungan Pasien Di Puskesmas Pembantu (Pustu)Desa Mamala Kecamatan Leihitu. Maluku Tengah. Provinsi Maluku

Risky B. Tombeng dkk, (2017). Analisis Kualitatif Kandungan Escherichia coli dan Coliform Pada 3 Depot Air Minum Isi Ulang Di Kota Manado (Skripsi). Fakultas Kesehatan Masyarakat Universitas Sam Ratulangi.

Riset Kesehatan Dasar, 2013, Badan Penelitian dan Pengembangan Kesehatan Kementrian Kesehatan Republik Indonesia tahun 2013diakses tanggal 29 April 2014.

Surtiningsih. 2010. Pencemaran Air. Surabaya: Karya Anda.

Sugiyono. (2013). Metode Penelitian Bisnis (Pendekatan Kuantitatif, Kualitatif, dan R\&D). Bandung: Alfabeta

Suripin, M. 2008. Pelestarian Sumber Daya Tanah dan Air. Yogyakarta. : ANDI

Todar, Kenneth. 2009. Bacteri pathogenesis.diunduh 15 Desember 2012.

Widiyanti, \& Ristianti. (2008). Analisis Kualitatif Bakteri Coliform pada Depo Air Minum Isi Ulang. Jurnal Ekologi Kesehatan , 64-73. 